Емилија Г. Јовић*

Филозофски факултет

Универзитет у Нишу
371.3::811.134.2'243

https://doi.org/10.18485/zivjez.2020.40.1.4

Кратко саопштење

\title{
ХУМОРИСТИЧКА РЕКЛАМА КАО ФРАГМЕНТ МЕДИОРЕКЛАМНЕ СЛИКЕ СВЕТА (НА ПЛАНУ РУСКОГ И СРПСКОГ ЈЕЗИКА)
}

У радусеразматрајукарактеристикеруске исрпскехумористичке рекламе у светлу постојања опште медиорекламне и језичке слике света као једне од особености савремених истраживања у области лингвокултурологије, журналистике, теорије медија, са тачке гледишта утицаја језика рекламног садржаја на свест и свакодневни живот савременог потрошача (корисника рекламе). Језик реклама одражава савремене појаве у социјалном и културном животу друштва, а такође он сам ствара нови смисао који одређује понашање већине људи. Предмет нашег истраживања представља савремена руска и српска хумористичка реклама доступна у руским и српским телевизијским програмима, интернет простору и јавним гласилима.

Кључне речи: хумористичка реклама, језичка слика света, медиорекламна слика света, руска хумористичка реклама, српска хумористичка реклама.

\section{1. Увод}

Реклама спадау ред феномена који се свакодневно развијају и мењају. Све чешће апелујући на осећања потрошача, аутори реклама користе различите, неретко иновативне начине реализације прагматичких функција рекламе. Тако се за један од ефектнијих приступа сматра употреба хумора и тежња ка постизању комичног ефекта, што у првом реду резултира привлачењем пажње. Када говоримо о тексту, тј. о реализацији

* emilija.jovic@filfak.ni.ac.rs 
хумора и комике у тексту, имамо на уму коришћење типичних средстава и метода.

Питање о типичним средствима изражавања комичног до данас остаје отворено у научној литератури, где највише пажње привлаче језичка средства која доприносе управо стварању комичног ефекта у различитим врстама дискурса. У нашем случају ради се о реклами, у којој се поменута средства користе са специфичним циљем.

Тако долазимо до посебног дела који одређује наше истраживање, а то је специфичан језик рекламе. Проблемима проучавања језика рекламе бавили су се бројни научници попут Николаја Николаевича Кохтева (1997), Светлане Јурјевне Тјурине (2009), Ангеле Годард (2002). Свакако нашу пажњу усмеравамо и на истраживања истакнутих руских лингвиста из области проучавања природе комичног, а то су Виктор Владимирович Виноградов, Александар Александрович Волков, Александар Наумович Лук (1968), Валериј Михајлович Макиенко (2001), Викторија Викторовна Сафонова (2013) и др.

\section{2. Реклама као део медиорекламне слике света}

Реклама представља комуникативно-социјалну појаву чији главни циљ је продаја робе и услуга. До данас имамо мноштво дефиниција рекламе. Н. Н. Кохтев у својој књизи Реклама: уметност речи истиче следеће:

Реклама је упозоравање људи свакојаким начинима зарад ширег сазнавања о нечему, што већег броја људи; информација о потрошачким својствима робе и могућностима различитих видова услуга с циљем њихове реализације и стварања активне потражње за њима; указивање на посебна дешавања економског, политичког и културног живота с циљем изазивања активног учешћа људи у њима. (Кохтев 1997: 3)

У процесу комуникације у сазнању примаоца информације путем рекламе конструише се посебна слика света, коју не 
ХУМОРИСТИЧКА РЕКЛАМА КАО ФРАГМЕНТ МЕДИОРЕКЛАМНЕ...

карактерише само прост пренос информација. „Комуникација - то је својеврсни упад у систем сазнања реципијента, изградња модела света у његовом когнитивном систему, који не мора нужно да се слаже са моделом света говорника и онтолошки постојећом сликом света" (Самосудова 2000: 170-174).

Функционално-прагматичко одређење хумористичке рекламе била би измена социокултурне реалности, промена услова понашања човека кроз корекцију његове индивидуалне слике света уз помоћ хумора. Хумор у свему томе има улогу посредника јер повезује постојећу свест о неком објекту из објективне стварности и нове поруке или информације о нечему што реклама нуди. У овом случају процес стварања хумористичке рекламе постаје процес образовања посебне врсте реалности - медија-реалности која поседује посебне карактеристике и посебну модалност. Медија-реалност се у највећој мери стапа са „аутентичном реалношћу у процесу стварања новости, пре свега телевизијских" (Ђакова 1999: 129).

Хумористичка реклама тако почиње да утиче на човекове навике и интересовања, те је због тога посматрамо као битан фрагмент медиорекламне слике света. Анализа текстова хумористичке рекламе наводи нас на закључке о томе да она формира такву медија-реалност чије карактеристике су елементи својствени класичним средствима изражавања хумора о којима ћемо касније детаљније говорити.

Са друге стране, са становишта лингвистике реклама је „вид говорне делатности чији циљ је регулисање понуде и потражње роба и услуга" (Костомаров 2004: 35). Савремена реклама је део индустрије која се бави производњом посебне текстуалне продукције (често вишекодовске, тј. оне која не користи само језик (вербални код), већ и музику, уметничка средства, фотографију... (Матвејева 2003: 431).

Рекламни текст има своје карактеристике. Истраживачи са енглеског говорног подручја примећују: „Реч 'текст' овде (примењена на рекламу) се користи у најширем смислу, укључујући визуелне артефакте, као и вербални језик" 
(Годард 2002: 6). Код већине рекламних текстова осим вербалних, налазимо и аудиовизуелне компоненте. Пошто их доживљавамо као недељиву целину која обухвата како писане, тако и усмене исказе, ови елементи се могу односити на различиту тематику, те зато и немају увек јасно дефинисану структуру. Текстови чија структура осим вербалних обухвата и нека средства иконичког карактера (фотографија, цртеж...), као и средства семиотских група (боја, величина фонта...) називају се креолизовани текстови (Сорокин и Тарасов 1990: 41). ${ }^{1}$ Они се састоје из два нехомогена дела: вербалног (језичког/говорног) и невербалног (припадност неким другим знаковним системима). По правилу, присуство невербалне компоненте схвата се као незаменљив атрибут пунозначног рекламног текста. Текст доживљавамо као одраз реалности, који постаје, сам по себи, само фрагмент те реалности (Тјурина 2009: 76-77).

Према Амири (2013) методе образовања креолизованих текстова, дакле текстова са вербалном компонентом и сликом, деле се на три основне групе:

1) вербални текст + слика: изворном тексту додајемо слике;

2) слика + вербални текст: илустративно-визуелним елементима додају се пратеће вербалне компоненте и

3) вербални текст = слика: текст изворно настаје као креолизован, где се вербалне и визуелне компоненте специјално бирају за могуће међусобно функционисање (Амири 2013: 31).

Под рекламним текстом, дакле, подразумевамо свеукупност аудиовизуелних средстава произвољне комбинације, који су усмерени на примаоца с циљем пружања планираног утицаја, директно или индиректно повезаног са објектом рекламирања. Како истиче Тјурина (2009: 3), обавезан минимални елемент рекламног текста је реч (ред бројева), скраћеница или симбол,

1 За потребе нашег рада чији су предмет хумористичке рекламе покушаћемо да у анализи обухватимо оба ова дела, јер пракса показује да хумору у многоме доприносе и визуелни ефекти. 
који при декодирању приказују предмет утицаја на примаоца. Ипак, значај вербалног језика у реклами је много већи, јер управо захваљујући лексичком тексту рекламна идеја добија реално остварење и почиње „да ради” (Добросклонска 2005: 288).

У процесу стварања текста рекламе аутори користе читав спектар језичких и ванјезичких средстава како би дошли до најефектније форме утицаја на примаоца. Тако у непосредна језичка средства убрајамо различита средства изражавања на свим језичким нивоима: алузију, метафору, поређење, паралелизме, понављања, алитерацију, ономатопеју, употребу императива и конотативних придева итд. (Добросклонска 2005: 289). За повећање изражајности рекламног текста може се истовремено користити више језичких средстава на различитим језичким нивоима. Одабир језичких средстава зависиће од критеријума информативности и афирмативности (позитивне оцене рекламе) (Дудина 2006: 5-18).

Када говоримо о визуелној компоненти у реклами, њена актуализација може бити реализована и помоћу графичких средстава, нпр. варијацијом фонта или писма. Невербални начини визуелне актуализације, с друге стране, подразумевају употребу пиктографских елемената, што потпомаже не само визуелну трансформацију рекламног текста, већ и ширење његових смисаоних граница (Амири 2013: 30-37), нпр. „Любим наших клиентов от всего $\boldsymbol{\vee}^{\prime} /$ срп. „Волимо наше клијенте од свег $\vee^{\prime \prime}$ (реклама туристичке агенције).

Како бисмо у раду истакли разлике између руске и српске рекламе, овде бисмо се на кратко осврнули и на радове српских истраживача који феномену рекламе приступају са различитих гледишта. Наиме, у истраживањима спроведеним на Институту за етнологију и антропологију Филозофског факултета Универзитета у Београду акценат је на антрополошком проучавању савремене рекламе, семиолошким методама, хронолошком праћењу развоја рекламе... Проучавање реклама „као дела медијског простора који учествује у процесу репродуковања ставова, избора и понашања, било да су они друштвени, економски или 
политички" релевантно је поље антрополошког проучавања (Милосављевић 2013: 34). Свакако, овим проблемом баве се и друге науке попут психологије, социологије, лингвистике.

\section{3. Карактеристике руске и српске рекламе}

Као што смо на почетку истакли, циљ нашег рада је да укажемо на основне разлике између руске и српске рекламе, кроз анализу средстава којима је у њима изражен хумор. Сам историјат развоја феномена рекламе у оба језика текао је под утицајем западне културе, те из тог разлога налазимо и бројне сличности.

Руска реклама је релативно нова социокултурна појава. Она се у многоме формирала под утицајем западне културе, конкретно америчке, услед чега постоје извесне разлике, али и сличности између њих (Амири 2007: 8-32). Ca једне стране је присутно обимно преузимање западних композиционих модела организације рекламног материјала, рекламних облика, лексичких средстава и карактеристичних синтаксичких конструкција, као и некритично преузимање облика западног потрошача и рекламера (Зирка 2005: 66-71).

Ca друге стране, у Русији, како истичу научници, реклама има улогу неке врсте уметничког текста, чак лепе књижевности, због чега је у руској реклами често интересантнији не сам предмет рекламирања, већ историја повезана са њим. „За разлику од западњачке рекламе која тежи спровођењу одређене идеје, најуспешнија руска реклама прича причу”, став је В. Рудњева (2002: 33). Зато се код руске рекламе посебна пажња не посвећује садржају, већ форми изражавања, што понекад доводи до нарушавања језичке норме.

На нивоу креолизованог текста у реклами, поменуто нарушавање се јавља у виду тзв. „шокантног приступа” (Амири 2013: 34), када организација текста и илустрација на основу двосмислености могу да изазову забуну или неразумевање.

Са чисто формалне и правне стране, у Русији налазимо и закон „О реклами” који утврђује појам неподобне рекламе 
(недобронамерне, нетачне, лажне, неетичне и скривене), али нема јасних разграничења у употреби конкретне лексике. Стога је у руским рекламама честа употреба речи-маркера неетичне рекламе (са сексуалним подтекстом или оне које садрже наговештај непристојне лексике (Имшинецка 2002: 17-29).

\section{1. Реализација комичног ефекта у реклами}

У литератури о стварању комичног ефекта среће се употреба бројних средстава. У радовима бројних руских и светских научника можемо издвојити игру речи, ауторске оказионализме настале сједињавањем разних речи, сатиру и хумор у хиперболи, алогизме, синтаксичку хомонимију, ауторске неологизме (Цикушева 2008: 169-171). Најпре бисмо покушали да опишемо природу комичног, да бисмо потом издвојили конкретна средства којима се остварује комични ефекат.

Термин „комично” је веома широке и опште природе. „Комика - је категорија естетике која у виду смеха изражава историјски условљено неслагање дате социјалне појаве, стварности и понашања људи, њиховог морала и обичаја са објективним током ствари и естетским идеалима прогресивних друштвених снага" (Фролов 1981: 445).

Комични ефекат општеупотребљиве лексике повезан је, пре свега, са могућностима њене метафоризације и вишезначности. Комика се појачава употребом појединих речи које се међусобно прате, достизањем додатне комичне обојености у комичном медију, путем неспоразума до којег долази у току дијалога итд. (Лук 1968: 192). Борев (1970) издваја следеће три форме комичног:

1) Хумор - представљање нечега у смешном, комичном облику,

2) Сатира - има омаловажавајући карактер, ствара нетрпељивост према објекту подсмеха и

3) Иронија - прелазна форма између сатире и хумора, средство необуздане, хладне критике. Објекат ироније је најчешће незнање (Борев 1970: 32-64). 
Када говоримо о језичким средствима, можемо их тумачити у ширем и ужем кључу. Све што доприноси стварању комичног ефекта у ширем смислу може се сматрати комичним средствима. У том смислу, та средства обухватају различите предмете и детаље.

Истичући језички аспект ових средстава имамо у виду следеће: епитет, метафора, метонимија, поређење, оксиморон, синонимија, антонимија, употреба клетви, псовки, похвала, вулгаризама, професионализама, титула... (Сафонова 2013: 474-478). Дата средства углавном карактеришу лексички и фразеолошки ниво језика. Тако, на пример, у сатиричним делима најчешће срећемо полисемију, хомонимију, синонимију и антонимију, комичну игру речи. Изговор речи са ироничном конотацијом доприноси већим могућностима њихове семантичко-комичне варијације. Комични ефекат производи и лингвистичко поигравање фигуративним изразима и афоризмима, паремијама, фразеологизмима итд.

Читав дијапазон могућности израза даје нам и игра речи (рус. каламбур). Каламбур није само проста игра речи. Он почива на значењу речи, неретко је повезан са њиховим различитим тумачењем, неочекиваним преосмишљавањем речи, па се понекад реч употребљава у потпуно другачијем, оказионалном значењу (Сафонова 2013: 477).

На фонетском језичком нивоу, у циљу постизања комичног ефекта, могу се користити: ономатопеја, спунеризам, метатеза, алитерација. Узроци комичности које налазимо у звуковним формама леже како у особеностима психофизичких механизама перцепције звучног тока говора, тако и у оном смислу, које човек као субјект културе даје звуковним знацима (Цикушева 2008: 170).

На стилско-граматичком нивоу једно од средстава изражавања хумора могу бити различите врсте одступања од граматичке норме као што су, на пример, погрешан ред речи, немогућа употреба тзв. „дупле негације” у енглеском језику и сл. (Цикушева 2008: 171). 
Аутори из области индустрије реклама, поред наведених језичких, истичу и следеће приступе комичном ефекту (Имшинецка 2002: 26):

1) Шала ради шале. У овом случају хумор није повезан са рекламним саопштењем, већ се употребљава само ради дужег остајања у свести потрошача;

2) Нарушавање прогнозе. Овај принцип подразумева неочекиваност, непредвидивост другог дела саопштења у односу на први;

3) Гротеска. Принцип подразумева употребу ликова, изграђених на контрастном, скоро језивом споју фантастике и реалности, преувеличавање одређених елемената;

4) Пародија. Овде је позната форма испуњена другим, понекад контрастним садржајем;

5) Пренос пажње. У овом случају пажња се концентрише на небитни детаљ;

6) Разбијање стереотипа. Дати принцип подразумева да се појава представља у необичном светлу;

7) Неочекивана поређења. У овом случају се користе неочекивана или немогућа поређења (нпр. човека са биљкама);

8) Прекид логичког низа. Дати принцип рачуна на домишљатост потрошача, у случајевима изостанка средњег члана у низу;

9) Супротстављање, контраст. Овде се користи неколико објеката, радњи или појава који заједно делују комично због антагонизма (мали-велики, јак-слаб...);

10) Недоследност. У датом случају лик или објекат се користи у недоследним условима или ситуацијама за њега. Ради се о нарушавању узрочно-последичних веза, корелацији времена и простора, када чудно и необично изазивају смех.

Сва ова средства искоришћена са врло јасним циљем у реклами која би требало да резултира што већим бројем прегледа на интернету, повећаном потражњом за одређеним производом или бољим пласманом на ранглисти најпраћенијих реклама, понекад подлежу и некој врсти статистичке анализе. Прецизне статистике о утицају 
и учесталости хумористичке рекламе у Русији и Србији не налазимо, мада многи аутори истичу да она „заузима веома приметно место у систему средстава масовне информације (СМИ)" (Макиенко 2001: 22).

\section{4. Врсте реклама и средства за изражавање хумора у руској и српској реклами}

Meђу традиционалним начинима класификације рекламних текстова издвајају се три, заснована на следећим критеријумима:1) рекламирани објекат, 2) циљна група потрошача и 3) средства масовне информације (СМИ). Према првом критеријуму класификују се групе рекламираних производа. По другом критеријуму рекламе се групишу у зависности од аудиторијума коме је намењена: омладини, женама, пословним људима и сл. Класификација према СМИ носачу реклама издваја следеће врсте реклама: штампана, телевизијска, реклама на радију и Интернет реклама. Дата класификација дозвољава да се пажња усмери на конкретна медијска средства рекламног текста, природно изражавајући оне његове особености које су условљене специјалним карактеристикама неког од средстава масовне информације (Добросклонска 2005: 164)

У нашем раду пажња је у највећој мери посвећена штампаној и спољашњој реклами, тј. оној где је рекламни текст праћен визуелним компонентама. Примере реклама које ћемо навести представљају, дакле, савремене облике вишекодовских текстова. Корпус који је послужио за анализу хумористичких реклама обухвата кратке форме рекламних порука у виду телевизијских реклама на руским и српским телевизијама², затим рекламне објаве на интернету (друштвеним мрежама) и визуелна рекламна саопштења

2 Рекламе су емитоване на телевизијским програмима кабловског оператера Exe net и доступне су и на Youtube-y, док су фотографије забележене праћењем друштвених мрежа (Instagram, Facebook). 
која имају за циљ дистрибуцију и продају услуга и производа. Анализирано је око 30 реклама које су биле доступне у току једногодишњег праћења извора.

Погледајмо како је један од најзаступљених облика руске и српске рекламе из истраживаног корпуса приказан језичким средствима за изражавање хумора, в. Слика 1:

Слика 1. Реклама за кафу

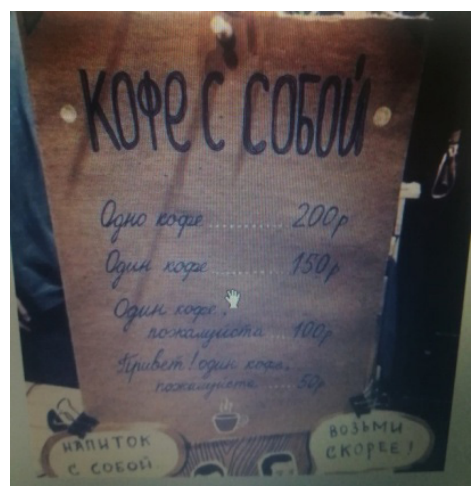

Слика 1. илуструје пример руске рекламе која изазива смех тиме што се путем игре купцу предлажу услови куповине. Разлика у роду именице кофе (у руском је мушког рода, а у српском језику ова именица је женског рода) додатно упућује на смисао рекламе: куповина ће бити повољнија уколико купац правилно употреби реч кофе у руском језику. У тексту се распоређивање информација одвија помоћу понављања уз додатне појашњавајуће детаље који конкретизују погодне услове куповине кафе. Осим тога, дату рекламо можемо сматрати и примером популаризације и побољшања друштвене писмености. 
Слика 2. Штампање новца

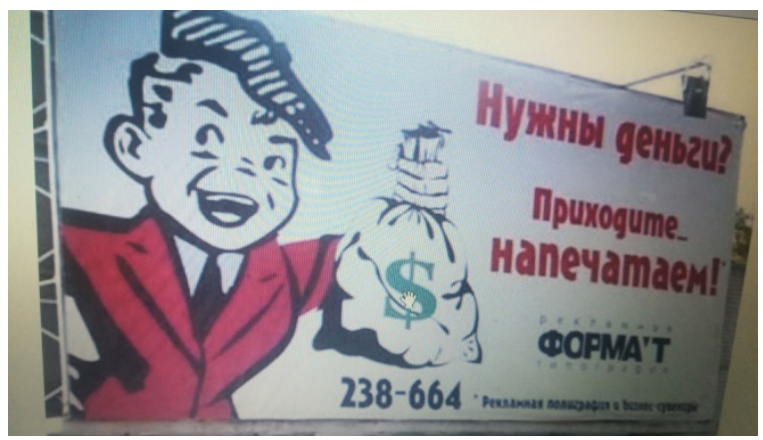

У примеру приказаном Сликом 2 искоришћена су лексичка, граматичка и графичка средства - питање које побуђује радњу и одговор-императив, где се представља шаљива ситуација на основу израза печатать деньги (срп. штампати новац) коју прати и одговарајући цртеж. Употреба „три тачке” се овде такође посматра као замена за дужу паузу.

Слика 3. Акција из супермаркета

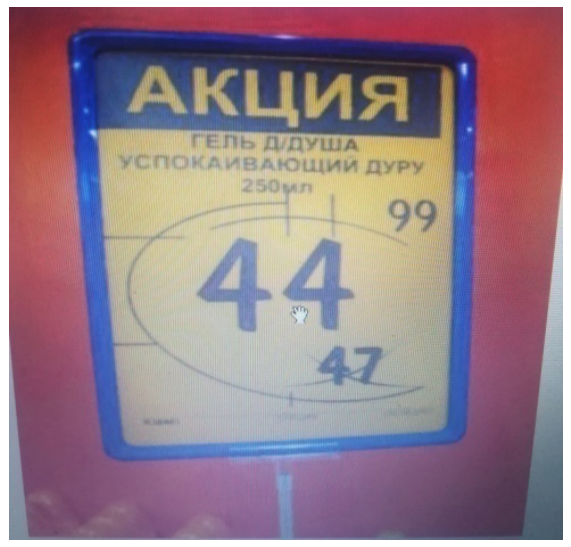

Рекламна акција из супермаркета илустрована Сликом 3 изазива смех због синтагме која садржи хомограф - уместо правилног изговора назива гела за туширање дуру́, може се 
прочитати ду́ру, где је значење потпуно другачије (рус. ду́ра значи глупа жена).

Слика 4. Лов и риболов

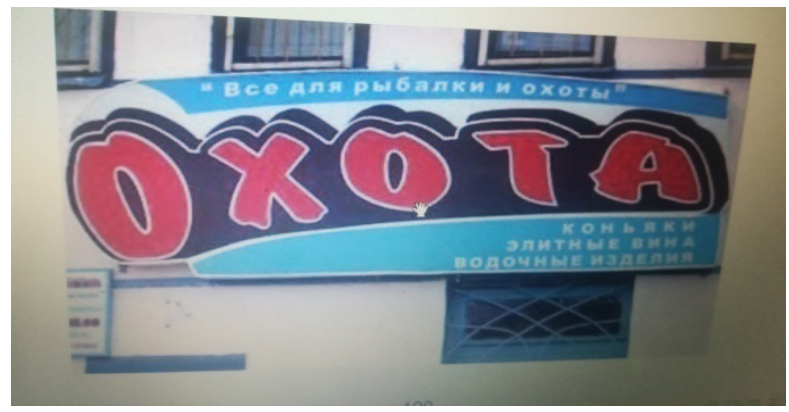

Сликом 4указујемо нарекламукојадемонстрира поигравање хомонимима у називу продавнице: лов живота и лов као жаргонски синоним речи жеља. Несумњиво је реклама упућена мушкарцима, чија се интересовања крећу у кругу риболова, лова и алкохола, чија опрема се може купити у тој продавници.

Са друге стране, рекламна саопштења која за циљ имају продају робе и услуга у српском језику представили бисмо следећим примерима:

Слика 5. Чај из ДМ-а

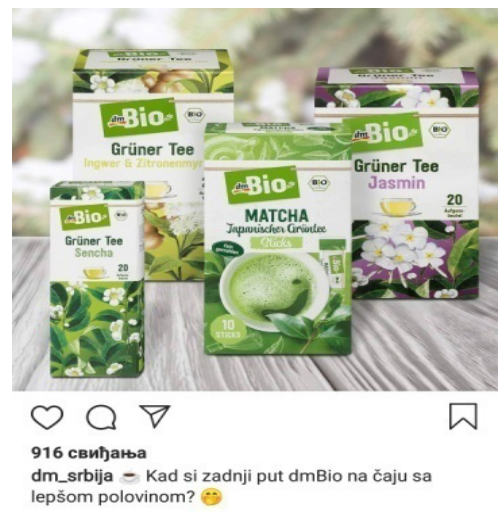


У реклами популарне врсте чаја (Слика 5) који указује на 100\% природне састојке, рекламна порука се ствара на основу употребе погрешног реда речи, што изазива комични ефекат код потрошача самим читањем назива рекламираног производа.

\section{Слика 6. Сајдер Бандит}

\section{Прави бандити поштују традицију. \\ Сајдер Бандит вам жели срећан Божић!}

\section{САJАЕР БАНАИТ ВАИСТИНУ БАНАИТ!}

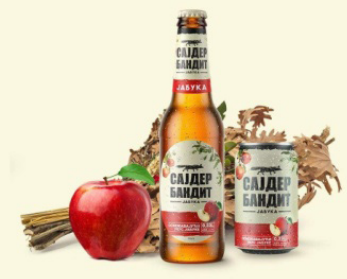

Слика 6 представља новију рекламу веома популарног напитка која је емитована на телевизији непосредно пред Божић 2020. године, где је искоришћен општеприхваћен религиозни поздрав за празник Божић, где се игром речи, тј. комбинацијом назива производа и поздрава привлачи пажња потрошача.

Слика 7. Плазма кекс

plazma_zvanicna

TVOJ PLAZMA RITUAL.SVE STO TI TREBA.

TRENING, MLEKO, BANANA $i$ 
Још један веома познат бренд у Србији у својој рекламној поруци (Слика 7) користи занимљив приступ шаљивом садржају. Наиме, текст рекламне поруке одговара реплици из домаћег филма Седам и поу коме главни лик као свој дневни мото користи реплику „плазма, млеко, банана”, а која је овде модификована и додатно појачана сликом рекламираног производа.

Када говоримо о радио и телевизијским рекламамау Русији и Србији, ситуација је прилично разнолика, од тематике, преко врсте реклама, па све до конкретних средстава.

Пример руске телевизијске рекламе „Почему так рано?"3 у основи садржи шаљиву презентацију брзине руске реконструисане железнице, где се путем анегдоте са неверном женом демонстрира новина у Русији. Језик је емоционално обојен строгим изразом, недовршеним мислима, а поентира се неочекиваном, смешном репликом једног од актера.

Новија српска реклама са хумористичком компонентом је поново у вези са брендом Плазма кекса, где је главни актер беба која још увек не говори, али је рекламна порука представљена унутрашњим монологом. У једном тренутку фокус је на прибору за јело, тј. кашики, за коју беба у себи поставља питање: „Каква ти је то гвоздена лопата?” Текст рекламне поруке нам на шаљив начин показује да познати бренд подједнако воле и деца и одрасли.

Посебна одлика српских реклама огледа се у врло честој употреби риме, где нам се рекламирани објекат презентује у виду слогана са стихом. Радио станица ТдИ радија има једну такву: „Купио сам ташти ламинат у инат!” (реклама робне марке Греенламинати).

Још једно идејно решење рекламне поруке познатог мобилног оператера у Србији ВИП је песма чија рима побраја све врсте трошкова на летовању једне породице:

Наруквице, кикице, сувлаки и гирос, лежаљке и сунцобран, све паре адиос! Нови фактор, нови душек, јапанке и костим, кукуруз, крофне, сладолед, а код куће ћу да постим! -

3 Линкови ка коментарисаним рекламама наведени су у Додатку. 
Море, сви сте хтели све, а како рећи не? Јуче ногице брчка, да, да, да, данас дужан к>о Грчка, да, да, да! Летос била Лефкада, сада парице нада! -А за сваку ситуацију, мама има комбинацију!

\section{5. Закључна разматрања}

Анализирајући руске и српске хумористичке рекламе са аспекта конфронтирања средстава за изражавање хумора, а под претпоставком разлике у националном хумору, односно постизања комичног ефекта, могли бисмо да укажемо на следећа запажања:

1) руски хумор је базиран на контексту, врло лако се издваја позадина садржаја рекламне поруке која често има традиционални карактер, и битнија је форма која често нарушава језичку норму; српски хумор је повезан са датом рекламном поруком и често указује на познату друштвено-културолошку позадину (реклама Плазма кекса и филма Седам и по);

2) оштрина хумористичких порука у руским рекламама најчешће је изражена на лексичком и фразеолошком језичком нивоу (стереотипи, рима);

3) руска реклама подсећа на западну, која је усмерена на тренутне, савремене потребе потрошача, кратког је и шаљивог карактера и поента рекламне поруке се најчешће налази на самом крају рекламе. Свему овоме такође тежи и реклама у Србији;

4) разлика у изражавању хумора у руском и српском језику огледа се у већој способности српских рекламних порука да лакше поприме дозу непристојног, некада и вулгарног, због кратких, ефектних форми рекламне поруке; у руској реклами можемо пронаћи и елементе лепе уметности, акценат је на причи коју добијамо из рекламе;

5) прецизна статистика о утицају хумористичких реклама на потрошача није карактеристична ни за руско, ни за српско говорно подручје;

6) српска реклама често користи стиховану ритмизацију као идејно решење у тексту рекламних порука. 


\section{ЛИТЕРАТУРА}

Амири 2007: Л. П. Амири, Языковая игра в российской и американской рекламе. Неопубликованная диссертация. Саратовский университет, Ростов на Дону.

Амири 2013: Л. П. Амири, Средства визуальной актуализации как графосемантическая разновидность языковой игры в креолизованных текстах рекламной коммуникации, Известия Саратовского университета, Том 13, Выпуск 2, 29-36.

Борев 1970: Ю. Борев, Комическое. Москва: Искусство.

Годард 2002: A. Goddard, The Language of Advertising. London: Routledge. Добросклонска 2005: Т. Г. Добросклонская, Вопросы изучения медиатекстов. Москва: Едиториал УРСС.

Дудина 2006: Е.П.Дудина, Семантика и функции лексико-грамматических единиц в рекламе. Неопубликованная диссертация. Поморский Государственный Университет им. М.В. Ломоносова, Архангелск.

Ђакова 1999: Е. Г. Дъякова, Массовая коммуникация и проблема конструирования реальности: анализ основных теоретических подходов. Екатеринбург: РАН.

Имшинецка 2002: И. А. Имшинецкая, Креатив в рекламе. Москва: РИП-холдинг.

Костомаров 2004: В. Г. Костомаров, Тексты масс-медиа. Москва: Журналистика и культура речи.

Кохтев 1997: Н. Н. Кохтев, Реклама: искусство слова. Москва: МГУ.

Лук 1968: А. Н. Лук, О чувстве юмора и остроумии. Москва: Искусство. Макиенко 2001: И. Макиенко, Юмор в рекламе. Маркетинг в России за рубежом, (5). Москва: Издательство «Финпресс».

Матвејева 2003: Т. В. Матвеева, Учебный словарь: русский язык, культура речи, стилистика, риторика. Москва: Флинта.

Милосављевић 2013: Lj. Milosavljević, Zašto su namćori otišli iz komšiluka? Predstavljanje starosti u domaćoj televizijskoj reklami. Etnoantropološki problemi, 8(1), 117-148.

Рудњев 2002: В. Руднев, В компании с толстяком: реклама и текст.Отечественные записки. Online, 2(3), [https://strana-oz. ru/2002/2/v-kompanii-s-tolstyakom-reklama-i-tekst].

Самосудова 2002: Г. Г. Самосудова, Художественный текст субъективный образ объективного мира / Концептуальная картина мира и интерпретативное поле текста с позиций лингвистики, журналистики и коммуникативистики. Барнаул: Санкт-Петербургский государственный университет. 
Сафонова 2013: Е. В. Сафонова, Формы, средства и приемы создания комического в литературе, Online, 5(52), [https://moluch.ru/ archive/52/6970/].

Сорокин и Тарасов 1990: Ю. А. Сорокин, Е. Ф. Тарасов, Креолизованые тексты и их комуникативная функция. Москва: Ин-т языкознания РАН.

Тјурина 2009: С. Тюрина, О понятиях рекламный дискурс и рекламный текст. Вестник ИГЭУ, номер 1, 1-3.

Фролов 1981: И. Т. Фролов, Философский словарь. Москва: Полиздат. Цикушева 2008: И. В. Цикушева, Лингвистические средства создания комического еффекта в сказках. Неопубликованная диссертация. Адыгейский государственный университет, Майкоп. 


\title{
Емилија Г. Јовић
}

\section{ЮМОРИСТИЧЕСКАЯ РЕКЛАМА КАК ФРАГМЕНТ МЕДИЙНО-РЕКЛАМНОЙ КАРТИНЫ МИРА (НА ПЛАНЕ РУССКОГО И СЕРБСКОГО)}

\begin{abstract}
Резюме
В статье рассматриваются характеристики российской и сербской юмористической реклам в свете общей медийно-рекламной и лингвистической картины мира как одной из особенностей современных исследований в лингвистике, журналистике, теории медиа с точки зрения влияния языка рекламы на сознание и повседневную жизнь современных потребителей. (пользователей рекламы). Язык рекламы отражает современные явления в социальной и культурной жизни общества, а также создает новый смысл, определяющий поведение большинства людей. Таким образом, реклама как более аспектное явление привлекает внимание исследователей в различных областях науки, включая лингвистику, журналистику, социологию, психологию. Предметом нашего исследования будет современная русская и сербская юмористическая рекламы, доступная в российских и сербских телепрограммах, Интернете и государственных СМИ.
\end{abstract}

Ключевые слова: юмористическая реклама, языковой образ мира, медиа-рекламный образ мира, русская юмористическая реклама, сербская юмористическая реклама. 


\section{Додатак. Линкови реклама}

Dorritos отличный улов: https://www.youtube.com/ watch?v=rijAXfqG13s

Free Cargo: https://yandex.ru/video/preview/?text=free\%20cargo $\% 20$ russian\&path=wizard\&parent-reqid=1609878421723955-

1637066286799678544500109-production-app-host-sas-web-yp$131 \&$ wiz_type $=v 4$ thumbs\&filmId $=13552942665524452528$

Биреклама: https://www.youtube.com/watch?v=aR_f_

E7LNss\&feature $=$ emb_logo

ВИП мобилна телефонија: https://www.youtube.com/ watch?v=FwoUhxq7IPE

Златни лав: https://www.youtube.com/watch?v=U9Vt2Di-Gs\&feature=emb_title

Лада Веста: https://www.youtube.com/ watch?v=E7dsEmHnpuU\&feature $=$ emb_titl

Морозная свежесть: https://www.youtube.com/watch?v=6Y_ MvAl4dy4

Московский картофель: https://www.youtube.com/watch?v=-qZXfKc_ qRw (Май, мойсковхск, мойкох.... МАЙНКАМПФ)

Не пей за рулем: https://www.youtube.com/ watch?v=hwXyxUuvACM\&list=PL_OYyhr2B7ux_ yOBNINiOnWPjtCibe4Q-\&index $=6$

Обезьяны и свежесть: https://www.youtube.com/ watch?v=i70bamFsBsg\&list=PL_OYyhr2B7ux_ yOBNINiOnWPjtCibe4Q-\&index=13

Орбит Павлин: https://www.youtube.com/ watch?v=jAPaFLmmftA\&feature=emb_logo

Плазма кекс: https://www.youtube.com/watch?v=xfUuKlPrmJM Помоги маме: https://www.youtube.com/watch?v=T5vF-

OFecf0\&list=PL_OYyhr2B7ux_yOBNINiOnWPjtCibe4Q-\&index=49

Почему так рано: https://yandex.ru/video/ 